\title{
TARZAN, UM NEGRO: \\ PARA UMA CRÍTICA DA ECONOMIA POLÍTICA \\ DO NOME DE "ÁFRICA"
}

Marcelo Rodrigues Souza Ribeiro (DD

Universidade Federal da Bahia

$\mathrm{N}$

o decorrer do século XX, assim como outras figuras do espaçamento colonial que constitui a modernidade, o nome de "Tarzan" se tornou uma matriz plural que não pode ser reduzida a um pertencimento cultural singular. Mesmo se sua genealogia pode ser retraçada a um contexto sociocultural preciso - aquele da publicação de Tarzan of the Apes, escrito por Edgar Rice Burroughs, ${ }^{1}$ no número de outubro de 1912 de uma pulp magazine chamada The All-Story, nos Estados Unidos - sua história permanece multiplicada entre diferentes paisagens culturais. Contudo, não se trata de uma passagem linear de uma genealogia ocidental a uma história transcultural: esta história afeta aquela genealogia como um suplemento. A história transcultural do nome de “Tarzan” é, ao mesmo tempo, uma derivação e uma condição de possibilidade (que pode ser reconhecida a posteriori) de sua genealogia ocidental.

Este ensaio busca identificar algumas características gerais do processo de disseminação histórica da figura de Tarzan, para que se torne possível compreender como se projetam, no personagem de Rice Burroughs e em suas derivas de sentido, ansiedades e ambivalências em relação a dois termos fundamentais da consciência colonial-moderna: África e raça. Depois de apresentar "Tarzan” como marca registrada e as derivas de sentido associadas às múltiplas apropriações de que o personagem pode se tornar objeto, busco reconhecer as ansiedades e ambivalências

1 Edgar Rice Burroughs, Tarzan of the apes, New York: Signet, 1990. 
que o constituem, desde sua emergência como parte de uma narrativa fantasiosa, racista e colonialista até sua disseminação (re)iterativa em diferentes contextos. Em seguida, apresento as características que definem a filmografia de Tarzan como maquinaria de representação da África, considerando brevemente o exemplo paradigmático de uma sequência do filme Tarzan the Ape Man (W. S. Van Dyke, 1932). Argumento, com base em estudo anterior mais abrangente, que a filmografia de Tarzan se caracteriza, de modo geral, pela relação entre as memórias de gênero do zoológico, do zoológico humano, do museu e do travelogue e os gêneros dominantes da aventura e do melodrama. ${ }^{2}$ Essa maquinaria inscreve o nome de "África" no que denomino uma nomenclausura ocidentalista da “África”.

Com base nessa incursão sobre a genealogia e a história proprietárias de Tarzan, passo a uma análise mais detalhada (ainda que limitada ao alcance de um ensaio) da reinscrição de “Tarzan” como o nome de um dos personagens africanos do filme Moi, un noir (Jean Rouch, 1959). O reconhecimento dessa reiteração subversiva permite discutir o regime epidérmico do racismo colonial-moderno que orienta a disseminação de Tarzan, ao mesmo tempo em que evidencia as ansiedades

2 Este texto reúne e revisa partes de minha dissertação de mestrado, intitulada "Da economia política do nome de 'África': a filmografia de Tarzan”, defendida em 2008 no Programa de Pós-Graduação em Antropologia Social da Universidade Federal de Santa Catarina, introduzindo alguns adendos e modificações, sem que tenha sido possível incorporar, no entanto, todas as referências da pesquisa anterior ou aquelas que foram publicadas posteriormente, dada a já longa extensão do texto. Uma versão menos extensa foi publicada em francês, em 2009, na revista Vibrant Virtual Brazilian Anthropology, no dossiê temático “Globalization and Circulation”, organizado por Bela Feldman-Bianco, Carmen Silvia Rial e Gustavo Lins Ribeiro, com o título "Tarzan, un noir : pour une critique de l’économie politique du nom «Afrique»". A versão em português aqui apresentada resulta de uma nova revisão do texto, que possui a forma de um ensaio e, nesse sentido, deriva por um itinerário dialógico necessariamente parcial e incompleto, sem que isso implique a ausência de base empírica, embora o objetivo deste texto não seja o de resumir ou retomar a análise da filmografia de Tarzan apresentada em 2008. É importante enfatizar ainda que a nova revisão conduziu a uma série de alterações significativas, que correspondem ao seu aspecto de ensaio teórico, como a inclusão de notas explicativas adicionais e um aprofundamento da parte final, dedicada ao diálogo com Achille Mbembe. 
e ambivalências que são constitutivas do personagem. Para pensar tais ansiedades e ambivalências, proponho compreender a relação de Tarzan com sua genealogia ocidental e sua história transcultural como uma relação de pertensimento (escrito deliberadamente com um s no lugar do c): um pertencimento constitutivamente tenso. ${ }^{3}$ Finalmente, com base em um diálogo com alguns argumentos que Achille Mbembe apresenta em Crítica da razão negra, ${ }^{4}$ procuro indicar como a compreensão da escritura da “África” na filmografia de Tarzan e em Moi, un noir pode ser situada em um processo mais amplo, que descrevo como uma economia política do nome de "África”.

\section{A economia da marca}

Abordar Tarzan implica considerar os regimes da propriedade privada no capitalismo: “Tarzan” é marca registrada, trademark ou tradename (®) de propriedade de Burroughs desde 1913, e pertence, atualmente, à corporação criada pelo autor, em 1923, para capitalizar os lucros do que escrevia. A Edgar Rice Burroughs Inc. é detentora do copyright de “Tarzan” e procura controlar a proliferação do personagem e garantir o princípio econômico do retorno circular dos valores e da circulação.

O que é a economia? Entre seus predicados ou seus valores semânticos irredutíveis, a economia comporta sem dúvida os valores de lei (nomos) e de casa (oikos, ou seja, a casa, a propriedade, a família, o lar e a lareira [le foyer], o fogo de dentro). Nomos não significa apenas a lei em geral, mas a lei de distribuição (nemein), a lei da partilha, a lei como partilha (moira), a parte dada ou designada, a participação. Uma

3 A palavra "pertensimento", escrita com um s no lugar do c, busca jogar com um erro de escrita para sugerir uma tensão silenciosa, mas profunda. O erro implica uma errância de sentido.

4 Achille Mbembe, Crítica da razão negra, São Paulo: n-1 edições, 2018. 
outra espécie de tautologia implica já o econômico no nômico como tal. Desde que há lei, há partilha: desde que há nomia, há economia. Além dos valores de lei e de casa, de distribuição e de partilha, a economia implica a ideia de troca, de circulação, de retorno. A figura do círculo está evidentemente no centro, se é ainda possível dizê-lo de um círculo. Ela está situada no centro de toda problemática da oikonomia, como de todo o campo econômico: troca circular, circulação dos bens, dos produtos, dos signos monetários ou das mercadorias, amortização das despesas, lucros, substituição dos valores de uso e dos valores de troca. Esse motivo da circulação pode dar a pensar que a lei da economia é o retorno - circular - ao ponto de partida, à origem, à casa também. Seria preciso, assim, seguir a estrutura odisseica da narrativa econômica. A oikonomia emprestaria sempre o caminho de Ulisses. ${ }^{5}$

No decorrer de suas refrações multimidiáticas, o nome de “Tarzan” se endereçará sempre a um retorno, por força da lei econômica que enquadra seus movimentos: legalmente, sua circulação está orientada por uma teleologia, e suas refrações se inscrevem sob uma injunção de retorno à domesticidade de uma corporação, sediada na cidade de Tarzana, na Califórnia, nos Estados Unidos da América.

Há, entretanto, diversos produtos que fazem alguma referência ao nome de "Tarzan” e que não foram autorizados pela ERB Inc. Considerando as aparições cinematográficas do personagem, Gabe Essoe menciona o controle exercido sobre o uso do nome de “Tarzan” pela ERB Inc. como uma limitação a adaptações e imitações, mas indica a dificuldade de conter, de maneira efetiva e completa, suas apropriações não autorizadas:

Paródias sobre Tarzan usando seu próprio nome foram limitadas por causa do estrito controle exercido sobre os direitos de filmagem relativos ao personagem. Porém, proteger tais direitos no domínio de

5 Jacques Derrida, Donner le temps, Paris: Galilée, 1991, pp. 17-18. Todas as citações de livros e textos em outras línguas foram traduzidas por mim. 
filmes de aventura não autorizados foi tão difícil quanto no campo da publicação de livros e revistas. ${ }^{6}$

De fato, Essoe cita alguns dos inúmeros exemplos possíveis, que é interessante considerar para pensar o que está em jogo nas restrições corporativas da ERB Inc. sobre o nome de “Tarzan”: o que é reprimido e o que é promovido pelo copyright?

O primeiro filme não autorizado de Tarzan conhecido foi The Adventures of Chinese Tarzan. Produzido pela Hsin Hwa Motion Picture Company de Singapura em 1940, este seria o primeiro de uma série de filmes. O Homem-Macaco era interpretado incrivelmente por um Peng Fei, e Lee Cha Cha aparecia como Jane Porter. Embora o filme tenha gerado longas filas em Xangai, nenhuma sequência foi realizada. Juntamente com as produções não autorizadas estavam os filmes pirateados. Quando estava em Nova York a negócios em 1944, Sol Lesser foi chamado por um distribuidor de filmes turco que disse a ele que tinha um filme turco de Tarzan para vender. Intrigado pela ideia, Lesser organizou uma exibição do filme, depois da qual ele o confiscou legalmente.

[...] Ralph Rotmund, gerente geral da ERB Inc. por longo tempo, interrompeu em 1954 a produção de uma série de filmes de Tarzan na Índia, depois que três tinham sido feitos.

Aparentemente, a operação, baseada na região de Berar, tinha fabricado maquinalmente filmes rápidos para distribuição na Nigéria. Em 1963, a atividade não autorizada aumentou horrendamente, devido à ideia equivocada de que alguns direitos de Tarzan estavam em domínio público. [...] A Cosmopolis Films, uma distribuidora francesa agora reportadamente falida, foi impedida pela ERB Inc. e pela Banner Productions de comercializar um filme de Tarzan feito na Itália

6 Gabe Essoe, Tarzan of the movies: 50+ years of E. R. Burroughs' legendary hero, New York: The Citadel Press, 1968, p. 203. 
chamado Tarzan, Roi de la Force Brutale. O filme, que foi realizado por Italia Produzione e Coronet Produzioni, estrelava Joe Robinson como o Homem-Macaco. Foi apreendido e lançado somente quando os produtores concordaram em mudar o nome do protagonista para Thaur antes de exibi-lo em qualquer lugar. Em outra ação, os advogados de Weintraub confiscaram o negativo de Tarzan chez le Coupers [sic] de Têtes, um filme francês feito por uma companhia italiana. Quando estava em Paris para o caso acima, o advogado representante de Burroughs e Banner também impediu que a Liberal Films distribuísse um filme de origem russa chamado Tarzan des Mers, que tratava de um homem anfíbio, Iktiandre [...]. O filme foi eventualmente exibido com o título The Amphibious Man.

Um quarto filme, Tarzan and the Jewels of Opar, foi interrompido depois de três dias de produção na Jamaica. Robert Hodes, então advogado e agora gerente geral da ERB Inc., venceu um embargo contra a Jamaica Pictures Ltd., comandada por Sherman S. Krellberg e Sandy Howard, e as filmagens foram permanentemente suspensas em 18 de novembro de 1964.

[...] Nada havia terminado, de forma alguma. Uma breve viagem à Checoslováquia impediu a distribuição de um filme chamado The Death of Tarzan. E quando uma nova companhia estadunidense comandada pelo diretor Ray Denis e pelo roteirista Ron Haydock anunciou planos de rodar Jungle Tales of Tarzan em Thousand Oaks, Califórnia, Hodes os informou sobre a posição jurídica da ERB Inc. [...] Hodes então soube que a Sargaam Chittra Ltd., uma empresa de cinema indiana, tinha feito de qualquer jeito dez filmes de Tarzan entre 1963 e 1965. Um lutador de luta-livre indiano chamado Darasingh interpretava o Senhor da Selva nos primeiros quatro: Rocket Tarzan, Tarzan and Delilah, Tarzan and King Kong e Tarzan Comes to Delhi. O papel foi então para um rapaz mais jovem chamado Azad, que completou seis filmes coestrelados pela "bela Chitra como sua companheira." Seus filmes foram: Tarzan and Cleopatra, Tarzan and the Gorilla, Tarzan's 
Beloved, Tarzan and Magician, Tarzan and Captain Kishore, e Tarzan and Circus. [...] Assim como com os filmes indianos feitos no começo dos anos 1950, essas produções "rapidinhas" foram exclusivamente para distribuição na Nigéria. E, assim como antes, a atividade posterior foi interrompida, e os negativos existentes, apreendidos. ${ }^{7}$

Os comentários de Essoe estão imbuídos de um tom laudatório que preza pela propriedade da marca registrada de "Tarzan" e promove a lei econômica de retorno à ERB Inc. No entanto, as informações que oferece revelam que a propriedade da marca registrada de “Tarzan” opera como uma censura, que incide tanto na domesticidade imperial quanto em territórios estrangeiros, projetando-se globalmente a partir do arsenal jurídico estadunidense.

Há ainda outros exemplos de apropriações não autorizadas do nome de “Tarzan”. Nos Estados Unidos, livros como Tarzan and the Silver Globe (1964), Tarzan and the Cave City (1964), Tarzan and the Snake People (1964), Tarzan and the Abominable Snowmen (1965) e Tarzan and the Winged Invaders (1965), assinados sob o pseudônimo de Barton Werper, foram retirados do mercado, e as cópias restantes ainda à venda foram destruídas. ${ }^{8}$ Em outras partes do mundo, a popularidade transnacional de Tarzan deu ensejo a diversas apropriações locais do personagem.

De acordo com o israelense Eli Eshed, após a tradução para o hebraico, na década de 1930, de alguns dos livros de Tarzan escritos por Burroughs, a popularidade do personagem cresceu exponencialmente. ${ }^{9}$ A este crescimento de popularidade correspondeu a criação de narrativas de Tarzan a partir de Israel (após 1948), isto é, narrativas cuja trama envolvendo viagens interplanetárias e no tempo, invasões alienígenas e outros elementos característicos do universo da ficção científica - projeta

7 Essoe, Tarzan of the movies, pp. 203-208.

8 Ed Stephan, Tarzan of the Internet $\boldsymbol{C}$.

9 Eli Eshed, “Tarzan in Israel”, 2011 飞. Eli Eshed assina um livro em hebraico sobre Tarzan em Israel, cujo título traduzido para o inglês é Tarzan in the Holy Land: The Adventures of Tarzan in Israel. 
e movimenta, em torno do nome de “África”, ansiedades ideológicas que fazem parte do processo de construção do Estado-nação israelense. Uma das consequências da refração de Tarzan pelo prisma de Israel reside na exacerbação da representação dos árabes como antagonistas, um tropo que remete a alguns dos livros de Burroughs e a muitos dos filmes protagonizados pelo personagem.

Entre inúmeras apropriações e imitações israelenses de Tarzan, destaca-se Dan-Tarzan, que Eshed descreve como "uma resposta sionista a Tarzan”. Segundo Eshed, Tarzan, Dan-Tarzan e outros lutam, nas narrativas israelenses, contra inimigos árabes, eventualmente aliados com nazistas em planos de dominação da África e/ou do mundo. A África representada nas narrativas israelenses é, na maioria das vezes, uma África sob dominação colonial britânica. No entanto, Eshed sugere que as narrativas de Tarzan “simbolizam” um “interesse” israelense na África, mais especificamente no quadro de um Estado-nação que busca estabelecer relações internacionais com nações emergentes, que se tornam independentes no pós-guerra. Nesse sentido, ele cita o exemplo de narrativas em que Tarzan aparece ajudando na luta pela independência em Biafra (região da Nigéria) e sugere a possibilidade de uma identificação de israelenses com Tarzan como o arauto da civilização entre os selvagens.

Em países árabes, entretanto, Tarzan também se difunde como um ícone cultural, desde os romances de Burroughs até os filmes, sob a forma de refrações localizadas que passam por outros prismas nacionais e coletivos. Segundo James R. Nesteby, as narrativas de Tarzan compõem "um dos mais influentes mitos culturais do século XX”. ${ }^{10}$ A região que Nesteby denomina largamente como "Arábia”, da qual fazem parte o Iêmen, o Líbano e a Síria, entre outros países, está permeada pelo “mito”

10 James R. Nesteby, “Tarzan of Arabia: American Popular Culture Permeates Yemen”, The Journal of Popular Culture, v. 15, n. 1 (1981), pp. 39-45 doo. O texto de James R. Nesteby é citado e descrito por Eli Eshed como "uma contra-parte ao meu artigo sobre Tarzan em Israel”. De Nesteby, ver também Black Images in American Films, 1896-1954: The Interplay between Civil Rights and Film Culture (Washington: University Press of America, 1982). 
de Tarzan, apesar do retrato em geral negativo de árabes (e de negros) que esse mito promove, segundo Nesteby.

Ao menos no final da década de 1970 (que é o período a que se referem os principais exemplos do autor), no Iêmen (que é o foco empírico de sua argumentação), Tarzan e seu universo chegam sob formas tão variadas em sua difusão quanto eficazes em sua cotidianidade: tiras de jornais diários estrangeiros (como o Indian Express ou o Kuwait Times), histórias em quadrinhos publicadas na Síria e no Líbano, filmes que já estiveram em cartaz em alguns cinemas locais (embora haja uma predominância de filmes egípcios e indianos) e outros artefatos variados, como figuras de plástico distribuídas em caixas de cereal para café da manhã e embalagens de gomas de mascar, entre outros.

Seja em Israel, onde é descrita e analisada por Eshed no contexto da formação do Estado-nação, seja no Iêmen, onde é descrita e analisada por Nesteby como um signo da colonização cultural da "Arábia” pela "cultura popular americana”, ou ainda em outras partes do mundo, a popularidade de Tarzan passa por uma política da narrativa que encerra uma dimensão de imposição e de dominação (enfatizada por Nesteby) e que descerra uma dimensão de negociação e de ressignificação (enfatizada por Eshed). Entre a dimensão de dominação e a dimensão de ressignificação, a política da narrativa que abriga “Tarzan ${ }^{\circledR}$ ” se deixa marcar por uma ambivalência.

Meu objetivo aqui não envolve a leitura analítica de todas as refrações de Tarzan. Ao citar a existência de produtos referenciados no nome de "Tarzan” que não foram reconhecidos nem autorizados pela ERB Inc., quero sugerir um argumento formal sobre a condição de possibilidade da economia da marca de "Tarzan”. Orientada por uma destinação de retorno à ERB Inc., a economia da marca se abre e se constitui pela iterabilidade como possibilidade estrutural: a possibilidade de citação, de enxerto e de reiteração - a diferença criativa que se encerra, como uma cripta, como um segredo, em cada repetição - constitui uma condição para a emergência de “Tarzan”. A lei econômica do retorno censura a disseminação (re)iterativa 
da marca de “Tarzan” e delimita uma destinação teleológica orientada para a domesticidade imperial.

Como marca, em sua iterabilidade, o nome de “Tarzan” se deixa habitar e se constitui sempre já por uma destinerrância, uma contra-lei de transbordamento que perturba sua destinação econômica. A citacionalidade amplificada da marca, a iterabilidade constitutiva de "Tarzan”, como um devir-errante irrestrito, antecede a lei que procura governar seus giros. A condição de possibilidade da lei econômica do retorno é a viagem dispersiva, o devir-errante da marca, o princípio de errância que a habita e a constitui: a destinerrância como condição da destinação. Um princípio de errância constitui a condição de possibilidade da lei da destinação econômica ao retorno re(con)stitutivo. Sulcando o espaço aberto da destinerrância, uma destinação econômica se impõe como uma censura que ali encontra sua condição negativa e essencial. A contingência se torna necessidade: a errância de “Tarzan” se torna o pano de fundo necessário para que alguma lei econômica venha tentar dar forma a seus giros.

Assim, a marca registrada de “Tarzan” se deixa habitar pela possibilidade de escapar à injunção econômica do retorno, por uma perturbação da teleologia que a destina à domesticidade da ERB Inc. e, talvez, pela possibilidade de transbordar o enquadramento imperial na imaginação da África (e do mundo). Escrevo “talvez”, pois a disseminação da marca de “Tarzan”, como mostram os exemplos de Israel e dos países árabes, não está necessariamente ligada a um transbordamento do enquadramento imperial ou a qualquer questionamento da colonialidade como estrutura de dominação política. Nenhuma teleologia política - seja colonial, anticolonial, pós-colonial etc. - governa de forma absoluta ou necessária a disseminação (re)iterativa de “Tarzan”. Após sua emergência como parte de uma narrativa fantasiosa que reproduz as coordenadas racistas e colonialistas do imaginário do sistema mundial colonial-moderno, o nome de "Tarzan” constitui um campo de batalha.

No decorrer de sua história, o nome de “Tarzan” não cessa de passar por diferentes lugares culturais, que se poderia, simplesmente e sem 
qualquer comentário suplementar, denominar “contextos”, se o valor de contexto e a lógica da contextualização não pertencessem à lei econômica que está aqui em questão. Nas passagens transculturais do nome de “Tarzan”, sua genealogia ocidental permanece em segundo plano, embora não completamente apagada - é possível ler por baixo da rasura.

A genealogia ocidental de "Tarzan” constitui um enquadramento de leitura, dando a suas ficções uma plausibilidade e um crédito dentro de uma moldura imperial, procurando garantir a propriedade de um contexto - isto é, tanto um contexto próprio (em que se pode compreender a atribuição de significado em jogo nas ficções protagonizadas pelo personagem) quanto a propriedade, a posse, a possessão de um texto, “Tarzan®”. O que uma consideração da história transcultural de “Tarzan” opera é o transbordamento do enquadramento genealógico, uma passagem além das bordas do Ocidente, inscrevendo-o no espaçamento transcultural que constitui o colonialismo e sua herança. A destinerrância torna necessário um enquadramento transcultural de leitura de "Tarzan” e de suas ficções, associadas ao que Marianna Torgovnick denomina "primitivismo ocidental". ${ }^{11}$

Se queremos levar Tarzan a sério, como propõe Torgovnick, é preciso reconhecer sua procedência estadunidense (“American” é o termo usado pela autora) e sua destinação a um público de "homens ocidentais falantes do inglês, apesar de uma ampla rede de circulação secundária”. Ao mesmo tempo, é também necessário pensar a deriva ambivalente que torna possível a preferência declarada de Torgovnick pelo que descreve como um "Tarzan cheio de dúvidas, disposto a aprender com negros e mulheres, disposto a perguntar e examinar a questão $O$ que um homem faz?’ Essa preferência, associada à deriva ambivalente que se intensifica na história transcultural de Tarzan, “corresponde a impulsos encontrados nos materiais originais de Tarzan”, associados a uma genealogia ocidental necessariamente impura, "mas gradualmente suprimidos nos romances e

11 Torgovnick, Marianna. "Taking Tarzan seriously" in Gone Primitive: Savage Intellects, Modern Lives. Chicago: University of Chicago Press, 1991, pp. 42-72. 
em abstrações populares de um Tarzan que bate no peito enquanto diz 'Mim Tarzan, você Jane' e domina os africanos”. ${ }^{12}$ Nesse sentido, reconhecer ao mesmo tempo a genealogia ocidental e a história transcultural de Tarzan torna possível compreender suas narrativas como um campo de forças, no qual "impulsos” que são "gradualmente suprimidos” podem retornar e assombrar o sujeito dominante, insinuando possibilidades de descentramento e de transbordamento.

Em seus itinerários globais, o nome de “Tarzan” atravessa inúmeras paisagens culturais, carregando representações da África que imprimem suas marcas nos comércios da imaginação. Se pertencem a uma genealogia ocidental que remete à modernidade, as narrativas de Tarzan refletem e refratam (nos elementos de que são feitas), assim como orbitam e habitam (na circulação a que estão sujeitas), uma história transcultural que remete ao colonialismo e à colonialidade como condições constitutivas da modernidade. O co-pertencimento das narrativas de Tarzan a uma genealogia ocidental e a uma história transcultural se produz como uma forma de pertensimento - um pertencimento tenso, silenciosamente perturbado ao sistema mundial colonial-moderno. ${ }^{13} \mathrm{O}$ maquinário narrativo que procura governar a filmografia de Tarzan tende à neutralização do pertensimento e à reafirmação teleológica do ocidentalismo, produzindo representações da África enquadradas pelo que chamo de nomenclausura ocidentalista da “África”.

\section{A nomenclausura ocidentalista da "África”}

Tarzan the Ape Man (W. S. Van Dyke, 1932) é um filme exemplar para a compreensão do que está em jogo na filmografia de Tarzan como

12 Torgovnick, Gone Primitive, p. 70.

13 Walter D. Mignolo, Histórias locais/projetos globais: colonialidade, saberes subalternos e pensamento liminar, Belo Horizonte: Ed. UFMG, 2003. 
maquinaria de representação da África. ${ }^{14} \mathrm{O}$ encontro de uma expedição ocidental (aquela de Jane, seu pai e Harry) com Tarzan é o centro de uma narrativa que envolve diversos elementos característicos da filmografia de Tarzan como uma totalidade articulada, ainda que de modo disjuntivo.

A expedição - um tropo que reenvia à memória de gênero do travelogue, do relato de viagem produzido como uma forma de apresentação das relações entre o sujeito ocidental e a alteridade colonial - está na África para buscar riquezas, particularmente um cemitério de elefantes ${ }^{15}$. Harry Holt e James Parker sonham com a abundância de marfim que ali encontrariam. Jane Parker chega à África para se reunir a seu pai e a Harry. A certa altura, Harry e James mostram a África a Jane e nós a acompanhamos. É o olhar de Jane que, no início, orienta o espectador diante da alteridade africana - uma branca diante dos negros. A encenação, caracterizada pela projeção de fundo durante a filmagem em estúdio, permitiu articular a imagem de Maureen O’Sullivan como Jane com imagens de arquivo de uma expedição na África, registradas para o filme Trader Horn (W. S. Van Dyke, 1931). ${ }^{16}$

14 Marcelo R. S. Ribeiro, "Da economia política do nome de 'África': a filmografia de Tarzan”, Dissertação (Mestrado em Antropologia Social), Universidade Federal de Santa Catarina, Florianópolis, 2008 ש. Para um diálogo mais detalhado com outras referências pertinentes ao estudo de Tarzan e de suas narrativas e imagens, remeto a esta dissertação, evitando que este texto assuma uma extensão ainda mais longa.

15 Johannes Fabian, Out of our minds: reason and madness in the exploration of Central Africa: the Ad. E. Jensen lectures at the Frobenius Institut, University of Frankfurt, Berkeley: University of California Press, 2000. Fabian analisa alguns travelogues que narram a exploração da África central e nos conduz a compreender as expedições como caravanas multiculturais, em cujo centro situam-se os europeus. Para o autor, é preciso dar mais importância à contradição do que à contestação (p. 6).

16 Esta cisão entre imagens de arquivo filmadas em locação e imagens filmadas em estúdio é também perceptível no domínio do som: há uma articulação de imagens sonoras registradas em diferentes partes da África com imagens visuais registradas em estúdio. A descontinuidade da encenação - que não é exclusiva de Tarzan the Ape Man (1932) - é, talvez, contraditória em relação à continuidade sugerida pela forma clássica hollywoodiana de integração narrativa. É precisamente tal descontinuidade contraditória que me interessa destacar aqui. Para uma análise da projeção de fundo (back-projection) como inscrição discursiva da "negação de contemporaneidade" que, segundo Johannes Fabian ( $O$ tempo e o outro: como a antropologia estabelece seu objeto, Petrópolis: Editora Vozes, 2013), constitui o “alocronismo" característico de diferentes modalidades antropológicas e etnográficas de fabricação 
Tudo se passa como se estivéssemos diante de um dispositivo de exposição de imagens que é comparável aos parques zoológicos. É precisamente para usar imagens de animais que as imagens de arquivo foram utilizadas diversas vezes no filme, mas o jogo do olhar que caracteriza o zoológico como memória de gênero se revela, aqui, numa forma de representação da alteridade que reenvia a outra importante memória de gênero que participa da filmografia de Tarzan. De fato, Jane apresenta a África aos espectadores como um espetáculo de zoológico humano:

As genealogias do fenômeno devem ser procuradas em formas muito diversas de cultura: o espetáculo dos "fenômenos monstruosos" (freaks) nos circos e as feiras atravessam o quadro do zoológico animal para produzir a configuração dos zoológicos humanos. As hierarquias, estabelecidas inicialmente pela ciência, precisam o lugar de cada grupo humano na grande escala das "raças". As difusões multiformes da espetacularização do Outro se estendem em seguida ao conjunto do Ocidente, nações colonizadoras ou não. Essas difusões são acompanhadas de declinações da encenação [mise en scène] do Outro e do exotismo em todas as esferas da cultura popular, da fotografia ao cinema, do cartão postal aos museus. Enfim, as permanências, através do século, dos zoológicos humanos, interrogam-nos sobre as perspectivas contemporâneas de um fenômeno que não foi nunca desconstruído. ${ }^{17}$

da alteridade, ver Teresa Castro, "Mapping Tarzan and Excavating Back-Projections: Rethinking Film History and the Politics of Time with Anthropology". in Alberto Beltrame, Giuseppe Fidotta e Andrea Mariani (org.), At the Borders of (Film) History: Temporality, Archaeology, Theories (Udine: Forum Edizioni, 2015), pp. 137-148. Minha leitura não diverge da análise de Castro, mas aqui estou mais interessado no modo como a cisão entre imagens de arquivo filmadas em locação e imagens filmadas em estúdio cria uma tensão no interior da trama discursiva do filme, convertendo a diferenciação entre as imagens (analisada por Castro como disjunção temporal que favorece e reproduz a "negação de contemporaneidade" à alteridade africana) em um resto inassimilável à teleologia narrativa e ao discurso fílmico. Esse resto pode insinuar possibilidades desconstrutivas.

17 Nicolas Bancel et al, "Introduction - Zoos humains: entre mythe et réalité” in Nicolas Bancel (org.), Zoos humains: au temps des exhibitions humaines, Éd. de poche (Paris: La Découverte, 2004), pp. 5-18. 
As imagens de animais e as imagens de seres humanos animalizados pelo olhar fílmico não participam completamente da integração narrativa do filme: como atrações, elas reenviam a um outro regime de construção da imagem cinematográfica - a mostração. De fato, um equilíbrio instável entre integração narrativa e atrações mostrativas marca toda a filmografia de Tarzan. ${ }^{18}$ Nesse sentido, é possível dizer que ela é atravessada por uma tensão entre o cinema institucional e a cinematografia-atração, nos termos de Gaudreault. ${ }^{19}$

A África se torna uma atração para o olhar ocidental, enquanto este olhar busca, obedecendo ao modo de endereçamento do filme, controlar os sentidos dos signos africanos, enquadrados pela teleologia melodramática da aventura. O melodrama e a aventura são os gêneros dominantes dentro da filmografia de Tarzan e operam para enquadrar as atrações e para (re)produzir uma teleologia que preconiza que o Bem (Tarzan e os brancos que ele representa) deve vencer o Mal (branco ou negro). O equilíbrio que tenta integrar as atrações nesse enquadramento teleológico é sempre instável, embora também poderoso. Nesse equilíbrio instável, é a interpelação do espectador que tenta fixar os papéis e controlar a leitura dos filmes. As memórias de gênero do zoológico, do zoológico humano, do museu e do travelogue são enquadradas por um olhar identificado à instância de narração que produz a integração das atrações na teleologia da aventura melodramática. ${ }^{20}$

A integração narrativa tenta constituir a branquidade como instância de narração: tudo se passa como se a branquidade fosse capaz

18 Há ainda a memória de gênero do museu, que se manifesta na apresentação de objetos como atrações que podem participar da integração narrativa, mas que reenviam também ao regime da mostração.

19 André Gaudreault, Cinéma et attraction: pour une nouvelle histoire du cinématographe, Paris: CNRS, 2008.

20 Para compreender as relações entre gêneros dominantes e memórias de gêneros menores, é fundamental pensar o problema dos gêneros discursivos, narrativos e artísticos com base em Mikhail Bakhtin, Os gêneros do discurso, São Paulo: Ed. 34, 2016. O pensamento de Bakhtin ressalta a questão do dialogismo. Cf. Mikhail Bakhtin, The dialogic imagination: four essays, Austin: University of Texas Press, 2011. 
de neutralizar as forças disjuntivas (em relação à integração narrativa) das memórias de gênero do zoológico, do zoológico humano, do museu e do travelogue; como se a posição de sujeito do branco fosse a única forma possível de subjetivação para os espectadores; como se o branco fosse a cor do olhar (e, portanto, o negro seria a cor sem olhar). Dessa forma, se as atrações mostrativas que participam da filmografia de Tarzan reenviam à cinematrografia-atração - caracterizada por uma forma quase carnavalesca de jogo inversivo e subversivo com as hierarquias -, a teleologia que tenta produzir a integração narrativa neutraliza a potência carnavalesca do que resta da cinematrografia-atração e enquadra as memórias de gênero do zoológico, do zoológico humano, do museu e do travelogue na maquinaria de gênero dominante, a aventura melodramática que projeta uma hierarquia na qual a branquidade é o horizonte preferencial de subjetivação.

\section{Tarzan, um negro?}

Como uma cripta, o nome de “Tarzan” encerra uma referência ao esquema epidérmico que é o fundamento do racismo colonial-moderno. Em “mangani”, a língua dos macacos que foram imaginados por Burroughs em seu livro de 1912, o nome de “Tarzan” significa "pele-branca”. ${ }^{21}$ Com efeito, mesmo se essa significação não é explicitamente mencionada nos filmes, a produção da diferença racial constitui uma obsessão que orienta a teleologia narrativa dos filmes de Tarzan. A cripta racista que habita o nome de "Tarzan” opera como um quadro de leitura de sua filmografia. É preciso sempre assumir determinadas posições de sujeito para ler um filme. Diante de um filme de Tarzan, a interpelação racial constitui uma forma privilegiada de subjetivação do espectador.

21 Burroughs, Tarzan of the apes, p. 52. 
Quando Frantz Fanon escreve, em seu livro Pele negra, máscaras brancas, publicado originalmente em 1952, sobre a "constelação de dados" e a "série de proposições" que trabalham para a formação psicossocial do sujeito e, mais especificamente, para a formação problemática (porque potencialmente psicopatológica) do negro como sujeito, é também em uma projeção de um filme de Tarzan que ele encontra a situação exemplar para seu argumento. ${ }^{22}$ Ele propõe ao leitor uma experiência: "assistir à projeção de um filme de Tarzan nas Antilhas e na Europa”. O espaçamento geopolítico colonial entre as Antilhas e a Europa duplica e perturba a cena da projeção, permitindo distinguir a injunção racial de subjetivação que orienta a filmografia de Tarzan e os limites dessa injunção de identificação: "Nas Antilhas, o jovem negro se identifica de facto com Tarzan contra os negros. Em um cinema da Europa, a coisa é muito mais complexa, pois a plateia, que é branca, o identifica automaticamente com os selvagens da tela”, ${ }^{23}$

O sentido atribuído por Burroughs ao nome de "Tarzan” "Pele-Branca" - orienta o posicionamento espectatorial e, portanto, a leitura preferencial dos filmes: imerso no ilusionismo narrativo, na fantasia projetada na tela, até mesmo “o jovem negro se identifica de facto com Tarzan contra os negros”. A identificação “com Tarzan contra os negros” procura governar a leitura do filme e tornar plausível sua ficção e sua trama. No entanto, como parece sugerir Fanon, a branquidade implicada no nome de “Tarzan” só pode ser apropriada por alguém de “pele negra” como uma máscara: a identificação do “jovem negro” com o protagonista branco encerra a violência de uma cisão subjetiva, expressa no título Pele negra, máscaras brancas.

A cena imaginada por Fanon situa a filmografia de Tarzan num espaçamento transcultural marcado pela colonialidade do poder que constitui o sistema mundial moderno. A significação racial do nome de “Tarzan” e a injunção racial de subjetivação que orienta a teleologia

22 Frantz Fanon, Pele negra, máscaras brancas, Salvador: Edufba, 2008, p. 135.

23 Fanon, Pele negra, máscaras brancas, p. 135. 
narrativa da filmografia de Tarzan podem ser lidos como sintomas da estruturação racista do sistema mundial colonial-moderno.

Num filme de Tarzan, a interpelação racial enquadra o olhar espectatorial e comanda a identificação "com Tarzan contra os negros” como uma condição de possibilidade e plausibilidade da leitura do filme. No entanto, o contexto da projeção é fundamental para seus efeitos de significação e delimita as possibilidades da injunção de subjetivação que está sempre em jogo quando se assiste a um filme. Na cena imaginada por Fanon, a dupla consciência do “jovem negro” - uma imagem do próprio Fanon no espelho, entre as Antilhas e a Europa, que é “Tarzan”, “pele-branca”, e o outro, negro, selvagem, numa encruzilhada de olhares - se torna o espaço de uma perturbação da injunção racial de subjetivação que procura governar a leitura do filme.

Nesse sentido, Fanon dá também indícios de como se perturba a injunção espectatorial, cuja realização, para o jovem negro na Europa, "é muito mais complexa, pois a plateia, que é branca, o identifica automaticamente com os selvagens da tela”. Por um lado, a atenção de Fanon à plateia sugere que um filme sempre se inscreve em espaços dinâmicos de tensão, de negociação e de disputa. Por outro lado, sua atenção à passagem dos filmes entre diferentes contextos (de recepção) sugere a necessidade de acolher, na leitura de qualquer filme, as possibilidades estruturais de desvio e de erro em relação à injunção preferencial.

A identificação do “jovem negro” com Tarzan assume uma dimensão crítica e inventiva em Moi, un noir (1959), um filme que uma postura cautelosa impede de inserir no corpus da filmografia de Tarzan, embora seu enxerto entre os filmes analisados possibilite criar uma tensão analítica crucial para a desconstrução das representações da África.

A direção de Moi, un noir (1959) é assinada por Jean Rouch, embora o filme tenha sido feito em colaboração com os sujeitos que o protagonizam, conforme o que Rouch denominava antropologia 
compartilhada. ${ }^{24} \mathrm{~A}$ assinatura de Rouch comanda o que o filme narra e mostra, limitando o compartilhamento do lugar de enunciação: sua voz demarca o andamento das cenas com comentários explicativos, embora seu corpo nunca entre em cena, o que o diferencia dos outros sujeitos envolvidos na produção do filme. Oumarou Ganda, Petit Touré, Alassane Maiga e outros entram em cena, assumindo o papel de personagens dentro de um enredo improvisado.

Ganda é Edward G. Robinson, Touré é Eddie Constantine e Maiga é Tarzan. Os três são jovens vindos do Níger para Abidjã, a capital da Costa do Marfim, em busca de trabalho e de dinheiro. A narrativa se estende por uma semana, de segunda a segunda, e acompanha Edward G. Robinson, passando por encontros com Eddie Constantine e Tarzan. Além de Rouch, as vozes de Robinson e Constantine se destacam na composição da narrativa, apresentando personagens e situações, dialogando, narrando eventos e comentando sua significação, preenchendo, portanto, o fluxo de imagens visuais com imagens sonoras. ${ }^{25}$

Dessa forma, em Moi, un noir, a assinatura de Rouch ocupa o lugar de instância de narração, seja por meio da voz em off, seja por meio do controle do trabalho de câmera e da montagem, enquanto os africanos envolvidos na produção, embora certamente não possam ser reduzidos a peças inertes nas mãos do diretor, desempenham papéis que se inserem ativamente na narrativa, mas permanecem subordinados ao seu andamento. Em todo caso, a hierarquia das assinaturas e das vozes de Moi, un noir guarda um potencial dialógico raro, que abre o filme a múltiplas possibilidades interpretativas e o transforma, de modo geral, em uma complexa articulação de comentários heterogêneos sobre o diálogo e seus limites na relação entre o Ocidente e a África.

24 Para uma discussão mais abrangente do cinema de Jean Rouch, ver o livro de Marco Antonio Gonçalvez, O real imaginado: etnografia, cinema e surrealismo em Jean Rouch. Rio de Janeiro: Topbooks, 2008.

25 A seguir, minhas traduções das falas do filme de Rouch tiveram como base as transcrições do áudio no idioma francês original. 
Filmado sem captação simultânea de som, Moi, un noir exemplifica um procedimento que Rouch denomina o "comentário improvisado 'na imagem'” [commentaire improvisé 'à l'image']: as imagens visuais, capturadas por Rouch quando acompanhava os migrantes em suas atividades diárias, são suplementadas pela voz do diretor e, de modo ainda mais crucial, pela polifonia das vozes dos atores, que foram gravadas a posteriori no decorrer de uma projeção do filme. ${ }^{26}$ Em vez de um comentário sobre a imagem, elevando-se acima dela com uma autoridade analítica e uma distância reflexiva, trata-se de um comentário na imagem, acompanhando seu fluxo, atravessando-a e sendo atravessado por ela, com intimidade.

A voz de Rouch abre o filme sobre imagens de Abidjã e de alguns dos personagens:

Todos os dias, jovens como os personagens deste filme chegam às cidades da África. Abandonaram a escola ou o trabalho nos campos para tentar entrar no mundo moderno. Nada sabem fazer e fazem de tudo. Eles são uma das doenças das novas cidades africanas: a juventude desempregada. Uma juventude encurralada entre a tradição e o automatismo, entre o Islã e o álcool, que não renunciou a suas crenças e se devota aos ídolos modernos do boxe e do cinema. Por seis meses, segui um grupo de jovens imigrantes nigerinos em Treichville, um subúrbio de Abidjã. Propus-lhes fazermos um filme em que representariam seu próprio papel, em que teriam o direito de fazer e falar o que quisessem. Foi assim que improvisamos este filme.

Após a apresentação do filme, Rouch resume e interpreta o que ocorreu com os dois protagonistas, Eddie Constantine, que acaba preso, e Edward G. Robinson, para quem, segundo Rouch, “o filme se

26 Jean Rouch, “O comentário improvisado na imagem” in Claudine de France (org.), Do filme etnográfico à antropologia fílmica (Campinas Editora da Unicamp, 2000), pp. 125-130. 
transformou num espelho onde ele descobriu a si mesmo: o ex-combatente da Indochina, expulso por seu pai por ter perdido a guerra. Ele é o herói deste filme, passo-lhe a palavra”. Tarzan, por sua vez, não fala, não comenta, não tem voz. Suas aparições no filme são sempre mediadas pela voz de Edward G. Robinson, exacerbando o jogo dialógico do comentário “na imagem”. A cada vez, Robinson opera como filtro, e Tarzan permanece um objeto de seu olhar e de seus comentários. Assumindo a voz de Robinson, Oumarou Ganda - que se tornou um importante cineasta africano (um dos prêmios do Festival Pan Africano de Cinema e Televisão de Ouagadugu, o FESPACO, leva o seu nome) - reflete sobre as relações entre a África e o cinema, por meio da figura de Tarzan, que trabalha como motorista de táxi e entra em cena pela primeira vez após seu nome aparecer em um letreiro de identificação de outro veículo de transporte.

“Bom dia, Tarzan!”, diz Robinson dirigindo-se àquele que aparece sentado na cadeira do motorista de um carro branco. Em seguida, em vez de dialogar, Robinson apresenta o amigo e fala de Treichville: “Quanto ao meu companheiro Tarzan, é um motorista de táxi. Meu velho, não é mole ser taxista, ainda mais em Treichville, a Chicago da África negra”. Enquanto Robinson fala, Tarzan parte com um cliente. A comparação de Treichville com Chicago encerra o movimento reflexivo que está em jogo em Moi, un noir: o espelho ocidental e, no caso, marcadamente estadunidense, constitui a tela fantasiosa na qual os sujeitos africanos projetam, interpretam e negociam sua existência, seus dilemas e seus sonhos, suas esperanças e seus problemas, sua melancolia. Assim, os pseudônimos que cada ator assume remetem aos "ídolos modernos do boxe e do cinema" de que fala Rouch no início, da mesma forma que uma série de signos que habitam a paisagem de Treichville: cartazes de filmes, um bar chamado “Mexico Saloon” (uma remissão menos ao México do que ao gênero do faroeste), entre outros. Nesse sentido, Moi, un noir aborda o lugar da fantasia e da imaginação entre os migrantes, que vivem entre o desenraizamento implicado no deslocamento geográfico e a desterritorialização implicada na colonização das paisagens mentais por signos e por imagens 
ocidentais - e, entre eles, Tarzan, nomeado com a marca registrada da ERB Inc.

Quando entra novamente em cena mais adiante, Tarzan não está dirigindo seu táxi, mas lutando boxe, dando socos em um saco de pancadas. Robinson diz:

Tarzan, meu grande amigo, meu grande companheiro é um boxeador profissional. Eu lhes disse que ele não se chama Tarzan por nada, é porque ele é boxeador. Olha como ele balança o saco, como bate nele. E ele precisa de um saco novo todas as semanas. Tarzan é forte. De verdade!

O nome de "Tarzan” evoca força, no discurso de Robinson em Moi, un noir, inscrevendo uma interpretação recorrente do significado do personagem de Burroughs em um contexto diferente: em vez de significar “Pele-Branca”, o nome de “Tarzan” significa força e designa um negro.

Entretanto, Robinson continua: "Queria muito ser como Tarzan, mas não tem jeito. Nada a fazer”. Robinson representa o lugar de enunciação subalterno, enquanto Tarzan, empregado e forte, ocupa um lugar menos desprivilegiado. Na sequência, sonhando com o sucesso no boxe, Robinson imagina-se como um campeão mundial, adotando o nome de "Ray Sugar Robinson” e escolhendo "Tarzan Johnny Weissmuller" como seu empresário, projetando uma espécie de conciliação fantasiosa.

A fantasia de Robinson revela as divisões e cisões que habitam o nome de "África”, sob o qual, contudo, se inscrevem unificadamente os personagens tanto no discurso de Rouch (que, embora localize seus pertencimentos, não hesita em tratá-los como representativos da África, como a juventude desempregada das “cidades da África”) quanto no discurso dos próprios atores, como exemplifica outro trecho do filme, quando, no domingo, Eddie Constantine narra um jogo de futebol. A certa altura, ele diz: “Segundo tempo. A África está dominando”. Em seguida, explicitando a identificação dele (e, por extensão, de Robinson e de Tarzan) 
com o time da África e demarcando a inscrição dos personagens sob o nome de "África”, Constantine acrescenta: “A África ganha e eu ganho uma mulher!”

Seja sob a forma de mulheres anônimas, seja sob a forma de personagens que assumiram pseudônimos como Dorothy Lamour, a figura da mulher desempenha um papel crucial na economia simbólica que se desenrola em Moi, un noir. Enquanto a vitória da África no jogo de futebol significa o acesso de Constantine a uma mulher, Dorothy Lamour é objeto dos investimentos amorosos de Edward G. Robinson.

Em outro momento, no sábado, o dia de folga, os amigos vão juntos à praia, no carro de Tarzan. Robinson novamente tem a palavra. Buscam Dorothy Lamour e Jane: "Tarzan deve estar feliz hoje, pois vamos à praia com Jane”. Quando chegam à praia, momentos depois, num dos instantes mais cruciais da mímica colonial ${ }^{27}$ que alimenta Moi, un noir, Robinson exclama: “Tarzan, o homem macaco!” e, em seguida, imita o grito que se consagrou com Johnny Weissmuller, numa identificação com Tarzan que encerra toda a promessa da fantasia e que descerra, em meio à alegria pelo dia de folga na praia, a melancolia da exclusão. Moi, un noir constitui uma ocasião para escutar algumas das vozes excluídas do sistema mundial colonial-moderno, comentando as fantasias e as formas de imaginação que o estruturam e o fundamentam. São sujeitos que pertencem ao sistema mundial colonial-moderno, mas sua inclusão e seu pertencimento se dão sob a forma estrutural da exclusão, do desenraizamento e da expropriação - configurando o que já começou a se escrever aqui: o pertensimento.

A alegria de ir à praia não afasta Robinson de sua melancolia: vendo todos felizes, ele se sente triste, pois todos os dias não são como aquele sábado. No domingo, igualmente, a Fraternidade Nigerina de Abidjã se reúne com festa, dança e alegria, sugerindo um sentido de comunidade que parece distante, no espaço e no tempo, do cotidiano dos migrantes. Mas o cotidiano retornará na segunda-feira, com a busca infrutífera de

27 Homi K. Bhabha, o local da cultura, BeloHorizonte: Editora da UFMG, 1998: 129-138 
trabalho, a vida na cidade em que são estrangeiros, sem dinheiro, sem esposa, sem destino.

Próximo do final do filme, num bar, Robinson corteja Lamour, até que um italiano entra em cena e desvia a atenção da moça, que deixa Robinson de lado. Pouco depois, em outro bar, lamentando sua solidão, bêbado, ele, Robinson, Oumarou Ganda, comenta: “É por isso que está essa bagunça. Este é nosso trabalho, ser mão de obra [...]. O cinema não é pra nós, não é pra nós, os pobres. Os outros são ricos”. Assim como Robinson gostaria de ser como Tarzan mas, como ele mesmo diz, não há "nada a fazer”, é sua voz que ouvimos formular a desilusão com a promessa do cinema: dizendo que “o cinema não é pra nós”, Oumarou Ganda critica a geopolítica que governa a produção cinematográfica mundial, que está relacionada à divisão internacional entre pobres e ricos. Seu comentário permite assinalar o lugar crucial do que Ngugi wa Thiong’o denomina “descolonização da mente” na luta pela reconfiguração da divisão internacional do trabalho: o trabalho da imaginação e da fantasia desempenha um papel decisivo na construção de subjetividades e de coletividades contemporâneas. ${ }^{28}$

Assim, é uma de suas fantasias que - pouco depois, em outro bar, do qual acaba sendo expulso por não pagar a bebida - Robinson projeta sobre figuras humanas desenhadas na parede: Dorothy Lamour será sua esposa e o esperará naquela que será sua casa. A propriedade da casa e a posse da mulher coincidem numa fantasia de reapropriação. "Dorothy Lamour vai me esperar à porta, porque será a minha casa”, sonha Robinson. “Eu serei o dono da casa e Dorothy Lamour será minha mulher”. Em off, a voz de Rouch dá o tom da transição do domingo de sonhos para a segunda-feira, pontuando o filme. Ao amanhecer, Robinson deixa o "Mexico

28 Ngugi wa Thiong'o, Decolonising the mind: the politics of language in African literature, Oxford: Currey, 2005. Ver também Ngugi wa Thiong’o, “A descolonização da mente é um pré-requisito para a prática criativa do cinema africano?” in Alessandra Meleiro (org.), Cinema no mundo: indústria, política e mercado: África (São Paulo: Escrituras Editora, 2007), v. 1, pp. 25-32. 
Saloon” e vai à casa de Dorothy Lamour. Lá, o italiano e ele brigam, até que Robinson vai embora.

O jogo de futebol de Constantine e a briga entre Robinson e o italiano encenam uma disputa por mulheres que pode ser lida, alegoricamente, como uma disputa pela África: a vitória da África no jogo se associa à realização do desejo de Constantine de conseguir uma mulher; o sucesso de Robinson com Lamour depende de afastar dela o italiano, um estrangeiro, um europeu, de modo a formar uma família e a garantir a propriedade do lugar - "serei o dono da casa".

À procura por trabalho e dinheiro no cotidiano dos migrantes soma-se o desejo e a disputa por mulheres, assim como, em grande parte dos filmes de Tarzan, o dinheiro, sob a forma de tesouros ou de mercadorias coloniais, perpassa as narrativas de forma recorrentemente articulada à disputa por mulheres. Tanto na filmografia de Tarzan quanto em Moi, un noir, o dinheiro e as mulheres se inscrevem numa economia simbólica que orbita o nome de “África”. Moi, un noir revela melancólica e dramaticamente a disputa pelo direito de escrever o nome de “África” que permeia a filmografia de Tarzan e sua disseminação transcultural, e que está em jogo na relação entre Ocidente e África no contexto do colonialismo e de sua herança. ${ }^{29}$

29 Será preciso interrogar os sentidos da inscrição das mulheres como ponto cego, por meio do silenciamento de suas perspectivas, nessa disputa pela escritura da "África" dominada pela perspectiva masculina. Embora não seja possível desenvolver essa linha de interrogação neste artigo, gostaria de sugerir um argumento básico, em linhas gerais. Se a filmografia de Tarzan pertence ao cinema narrativo clássico, que Laura Mulvey, "Prazer visual e cinema narrativo" in Ismail Xavier (org.), A experiência do cinema: antologia (Rio de Janeiro: Edições Graal; Embrafilme, 1983), pp. 437-453, descreve e confronta como um cinema baseado na objetificação do corpo feminino, com o intuito de produzir prazer visual para o sujeito masculino do olhar, conforme uma injunção espectatorial patriarcal, Moi, un noir evidencia o modo como a colonialidade do poder reproduz a estruturação patriarcal do olhar cinematográfico em outro contexto, a despeito da hierarquia que opõe colonizadores e colonizados. Nesse sentido, o silenciamento da perspectiva das mulheres em Moi, un noir não é apenas uma reprodução colonialista do "inconsciente da sociedade patriarcal [que] estruturou a forma do cinema” (Mulvey, "Prazer visual e cinema narrativo”, p. 437), no contexto da sociedade colonizadora (os Estados Unidos e os ícones de Hollywood, reverenciados pelos sujeitos do filme de Rouch), mas uma decorrência do que se 
No cinema ocidental, as aventuras de Tarzan se enquadram numa teleologia melodramática cujo horizonte moral e ético consiste na (re)produção do Ocidente como fórum cultural mundialmente hegemônico em que se decidem totalmente os destinos das outras partes do mundo. Nesse sentido, a inscrição do nome de “África” na filmografia de Tarzan obedece a uma imaginação ocidentalista. ${ }^{30}$ Em Moi, un noir, a inscrição do nome de "África” dentro de um regime imaginativo ocidentalista é comentada e questionada de forma ativa e reflexiva: o filme insinua uma excrição do nome de "África”, revelando que se trata de um campo de batalha em que se projetam os desejos e as ansiedades, as fantasias e as aporias de diferentes posições de sujeito.

Se, para os migrantes que o filme acompanha, a cidade constitui um espaço de promessas não cumpridas e aspirações recusadas, a fantasia constitui um espaço que insinua a reinvenção transformadora, embora passageira, da vida. Como argumenta Anna Grimshaw, Robinson “e seus amigos são excluídos da cidade. Eles vão e vêm dentro dela, mas têm recusada qualquer conexão real com ela. Como eles, nós compartilhamos a experiência de estar sempre observando de fora”. ${ }^{31}$ Diante da exclusão, a fantasia representa um último recurso, explorado sobretudo por Robinson:

O que permanece disponível para ele, porém, é a fantasia. Ela se torna o meio pelo qual ele é capaz de expressar sua própria subjetividade, sua agência, sua criatividade diante da recusa da cidade em reconhecê-lo. [...] Mas ela só pode ser uma liberação temporária em relação

pode reconhecer como a transversalidade do gênero como idioma e como estrutura de subordinação e de dominação. Cf. Rita Laura Segato, Las estructuras elementales de la violencia: ensayos sobre género entre la antropología, el psicoanálisis y los derechos humanos, $2^{\mathrm{a}}$ ed, Buenos Aires: Prometeo, 2010. Para uma discussão dos problemas de gênero associados à emergência dos cinemas africanos, ver meu texto “Desterro, desejo, delírio”, Grandes Clássicos do Cinema Africano ש.

30 Fernando Coronil, "Beyond Occidentalism: Toward Nonimperial Geohistorical Categories”, Cultural Anthropology, v. 11, n. 1 (1996), p. 51-87 ש.

31 Anna Grimshaw, The Ethnographer's Eye: Ways of Seeing in Anthropology, Cambridge, Massachusetts: Cambridge University Press, 2001, p. 111. 
às limitações de sua situação, e o filme volta Robinson ao confronto de mais uma segunda-feira como um migrante em busca de trabalho. Ele sonha em ir para casa. Imagens da vida numa aldeia nigerina prometem a felicidade que escapou dele na cidade. ${ }^{32}$

De Tarzan of the Apes, suas seqüências e suas refrações multimidiáticas a Moi un noir, é legível a forma como o registro de “Tarzan”, sua trademark, se espalha pelas redes do entretenimento capitalista e, ao mesmo tempo, se dissemina e se dissolve, sem retorno, em ficções e em fricções que pertensem às redes do capitalismo, inscrevendo-se sob rasura. De Burroughs a Jean Rouch - não se trata de uma passagem cronológica - Tarzan enegrece, numa brincadeira meio louca, conforme à disseminação de seu nome próprio em nomes comuns, rasurando-se a si mesmo: a "pele branca" se escreve com uma tinta escura, negra, preta, como piche, tar - zany, ${ }^{33}$ num movimento desvairado, como num jogo sem sentido, numa piada tola. ${ }^{34}$

Tarzan, um negro: a identificação com Tarzan se revela em toda sua ambivalência, pois implica, ao mesmo tempo, uma sujeição ao homem branco como sujeito privilegiado na tela - a identificação “com Tarzan contra os Negros” de que fala Fanon, que reitera a cisão subjetiva resumida na expressão “pele negra, máscaras brancas” - e uma sujeição do homem branco como sujeito subvertido - a identificação com/de Tarzan como um negro, um selvagem, um primitivo - através da abertura do enquadramento da tela, passando, por meio de um certo jogo de desenquadramento, de

32 Grimshaw, The Ethnographer's Eye, p. 111.

33 No Oxford Advanced Learner's Dictionary, tar é: “black substance, hard when cold, thick and sticky when warm, obtained from coal, etc. used to preserve timber (eg in fences and posts), making roads, etc.”. A respeito de zany, lê-se: “foolish; mad”.

34 Gregory Ulmer sugere que a "decomposição do nome” é uma das formas de escritura de uma "gramatologia aplicada" (que ele propõe lendo Derrida). Meu argumento afirma que é legível uma decomposição disseminante do nome de “Tarzan” através da rasura sob a qual se inscreve em Moi, un noir. Cf. Gregory L. Ulmer, Applied grammatology: post(e)-pedagogy from Jacques Derrida to Joseph Beuys, Baltimore: Johns Hopkins University Press, 1985. 
uma moldura ocidental a uma moldura transcultural. Trata-se de um jogo que reinventa os sujeitos envolvidos, numa espécie de transe transcultural.

Embora Moi, un noir não seja, geralmente, associado à questão do transe, o cinema de Jean Rouch constitui um espaço estético e intelectual privilegiado para o estudo do transe como experiência social e cultural. Muitos de seus filmes abordam rituais de possessão, e Rouch refletiu com frequência sobre o transe e sua representação cinematográfica, sobre o lugar do cineasta-antropólogo diante dos sujeitos filmados e sobre outras questões críticas, sugerindo que a câmera cinematográfica pode desempenhar um papel no desencadeamento do transe, o que configuraria o que ele denomina cine-transe. A partir de uma comparação com Les Maîtres Fous (1955), um dos filmes de Rouch que documenta um ritual religioso de possessão, gostaria de propor a ideia de que Moi, un noir constitui um exemplo não religioso de cine-transe.

Sobre o filme de 1955, Anna Grimshaw escreve:

Les Maîtres Fous [...] documenta o andamento de uma cerimônia de possessão realizada durante um domingo por membros da seita Hauka que são trabalhadores migrantes em Accra. Emergindo na colônia do Níger durante a década de 1920 como uma forma de resistência ao domínio colonial francês, o culto se estabeleceu entre pessoas que tinham se mudado de suas aldeias rurais para encontrar trabalho em Kumasi e em Accra, as áreas comerciais da Costa do Ouro, controlada pelos britânicos. Durante a cerimônia, seus membros passam por uma violenta possessão de espíritos, assumindo as identidades de seus mestres coloniais; e, como sugere a ambiguidade contida no título do filme de Rouch (quem é louco - os administradores coloniais ou seus imitadores... ou ambos?), o culto dos Hauka questiona as hierarquias convencionais de poder e racionalidade..$^{35}$

35 Grimshaw, The Ethnographer's Eye, p. 93. 
Grimshaw sugere também que "Les Maîtres Fous é não apenas sobre possessão, mas uma ocasião de/para possessão". ${ }^{36}$ O que me interessa reter como eixo de comparação entre os dois filmes é o gesto, comum aos sujeitos representados em ambos, de assumir as identidades dos colonizadores, sejam figuras da história, sejam existências de fantasia. Em Les Maîtres Fous, os Hauka são possuídos por espíritos de administradores coloniais e de suas esposas, de exploradores europeus e de personagens imperiais; da mesma maneira, em Moi, un noir, os migrantes assumem as identidades de ídolos ocidentais do esporte e do cinema, que se projetam mundialmente, como Tarzan, por meio das estruturas coloniais que organizam as relações entre o Ocidente e outras partes do mundo. Tanto no ritual apresentado em Les Maîtres Fous quanto na elaboração de Moi, un noir, está em jogo um gesto que Paul Stoller, discutindo o culto religioso dos Hauka na África Ocidental, descreve como “corporificar memórias coloniais”. ${ }^{37}$ A filmografia de Tarzan, compreendida como um arquivo de memórias coloniais, deve ser interrogada a partir do gesto de desconstrução implicado em sua corporificação.

Da construção fílmica - com a antropologia compartilhada entre Rouch e os sujeitos do filme; com o comentário na imagem exacerbando a crise e a crítica encenadas e documentadas - até os temas que aborda em sua narrativa e em sua mise-en-scène - a urbanização da África Ocidental, o lugar social da fantasia e da imaginação - Moi, un noir acentua a disseminação e o descentramento de "Tarzan" e representa a possibilidade de desconstruir a nomenclausura ocidentalista da “África”, embora não a realize completamente.

Entretanto, a figuração da desconstrução da nomenclausura ocidentalista da “África” na rasura do nome de “Tarzan” em Moi, un noir não advém como uma perturbação a partir de fora: sua estranha familiaridade já se encontra prefigurada, como potência e como possibilidade,

36 Grimshaw, The Ethnographer's Eye, p. 94.

37 Paul Stoller, Embodying colonial memories: spirit possession, power, and the Hauka in West Africa, New York: Routledge, 1995. 
na estrutura das narrativas de Tarzan e, de forma singular, nos filmes no abalo da teleologia narrativa produzido pelas memórias de gênero de formas culturais opacas à narrativização cinematográfica clássica, ligadas ao universo do primeiro cinema.

A utilização de formas culturais típicas do cinema de atrações e opacas à narrativização clássica (a qual as submeteria à injunção da espectatorialidade dos filmes de Tarzan) também perturba, de outra forma, em outro nível, a economia psíquica da narração que procura fechar o sentido das representações movimentadas e delimitar a nomenclausura ocidentalista da “África”. A fenda aberta, pelo que resta do cinema de atrações, entre os filmes de Tarzan e a narrativização, é o espaço do descentramento disseminante que possibilita, em Moi, un noir, por exemplo, rasurar o nome de "Tarzan” e exacerbar a fricção do seu pertensimento. A partir dessa perturbação em diferentes níveis da injunção da espectatorialidade, borra-se a legibilidade das ficções de Tarzan e cinde-se o registro de sua marca, o capital de sua trademark.

Se o estereótipo - uma estratégia de representação fundamental para a filmografia de Tarzan - constitui um fetiche que trabalha no sentido de delimitar posições de identidade e diferença de forma fixa, o pertensimento revela o que o fetiche mascara - a contingência irredutível da produção de identidades e de diferenças - e perturba o que o estereótipo consolida - uma versão fixa da política da identidade. Pele branca, máscaras negras: a ambivalência de “Tarzan” borra a política de identidade essencialista que procura contê-lo e enquadrá-lo. Nos contextos através dos quais a indústria cultural, da literatura ao cinema e à televisão, faz circular seus produtos, a fricção de “Tarzan” toma lugar com a intempestividade de um borrão. O enxerto do $r$ na palavra "ficção” marca, ao mesmo tempo, o desgaste de "Tarzan" como marca registrada e a perturbação de suas ficções. A substituição do $c$ pelo $s$ em pertensimento marca silenciosamente a différance entre ficção e fricção, entre “Tarzan®” (como marca registrada que pertence a uma genealogia ocidental) 
e "Tarzan” (como marca aberta em sua iterabilidade, que pertense a uma história transcultural). ${ }^{38}$

A disseminação de "Tarzan” e o descentramento de sua marca, cuja possibilidade não cessa de se insinuar, cindem o círculo econômico com a ambivalência de suas paisagens transculturais, perturbando a lei econômica que preconiza o retorno do capital de “Tarzan®” à domesticidade da ERB Inc. Se, como argumenta Jean Baudrillard, a ambivalência cinde o valor/signo e "põe fim à economia política do signo", a ambivalência de "Tarzan", como parte do trabalho de sonho do imperialismo, pode pôr fim à economia política do nome de “África”, interromper a ordem de seus regimes. ${ }^{39}$ Tarzan pertence à nomenclausura ocidentalista da “África” como regime hegemônico da economia política do nome de “África”, mas sua ambivalência possibilita o descentramento: o pertensimento ao oikos pode se produzir como cisão do nomos.

\section{Para uma crítica da economia política do nome de "África”}

O nome de “África”: desde já deriva e disseminação diaspórica o tornam irretornável a uma origem e multiplicam o jogo de suas apropriações e expropriações. Não se trata de uma categoria social que se pode atribuir a um universo cultural e simbólico particular ou à consciência humana em

38 Opto por manter o termo francês de Derrida, para ressaltar sua intraduzibilidade. Lembro ainda, entre outras propostas de tradução de différance em português, o uso de "diferança”, que reproduz a introdução do a no lugar do e que está em jogo no francês de Derrida, assim como a possibilidade de grafar a palavra como diferensa, conforme um procedimento de substituição do ç pelo s que não altera a pronúncia da palavra, assim como ocorre com a substituição do $e$ pelo $a$ (da grafia padrão, différence, para a grafia desconstrutiva, différance); é o mesmo procedimento que está em jogo na tradução por dyferença, assim como na minha proposição do conceito de pertensimento. Sobre o conceito de différance, cf. Jacques Derrida, Margens da filosofia, Campinas: Papirus, 1991.

39 Jean Baudrillard, Para uma critica da economia politica do signo, Lisboa: Edições 70, 1995, p. 187. 
geral: o nome de “África” - “África”, ‘Afrique’, ‘Afrik’... - atravessa universos culturais e simbólicos diferentes e permanece uma matriz significante. É preciso pensar a escritura da “África” como um processo inconcluso e aberto de produção de sentidos sobre o que é a identidade africana, a africanidade e o elemento afro-, que abrange diferentes lugares históricos e posições de sujeito, diversas práticas discursivas e imaginativas.

A escritura da "África” configura uma dialética indecidível entre inscrição e excrição do nome de "África” e dos signos que o orbitam e o habitam. Não há síntese final, não há horizonte teleológico de conciliação ou de superação, não há um porto que transcenda e funde a deriva originária do nome de “África”. Há mo(vi)mentos de articulação. Na inscrição do nome de “África”, dá-se uma atribuição de sentido e a produção de significados, enquanto a excrição do nome de “África” é o momento dialeticamente oposto e virtualmente simultâneo de descolamento entre significante e significado, de instabilidade e de abertura para outras possibilidades.

Entre seus predicados fundamentais no discurso contemporâneo, o nome de “África” guarda uma relação histórica constitutiva com o predicado racial associado ao conceito de 'negro', na medida em que, como escreve Achille Mbembe, "uma relação de coengendramento liga esses dois conceitos”, que "remetem à diferença mais pura e mais radical e à lei da separação”. ${ }^{40}$ Considerando que “o substantivo ‘negro’ preencheu

40 Mbembe, Crítica da razão negra, p. 79. Esta parte final do texto dialoga extensivamente com argumentos que Achille Mbembe apresenta neste livro, por isso o autor é citado de forma recorrente. Optei por me concentrar apenas nesta obra de Mbembe devido à extensão já bastante longa do que apresento aqui. A mesma razão explica por que não elaboro possíveis diálogos com obras de outros pensadores fundamentais para a compreensão da África como invenção transcultural (e não meramente ocidental), como Valentin-Yves Mudimbe, entre outros. Cf. A invenção da África: gnose, filosofia e a ordem do conhecimento, Petrópolis: Vozes, 2019; A ideia de África, Ramada: Pedago, 2016. De modo geral, o diálogo com a linhagem de que participa Mudimbe me parece fundamental para explorar possibilidades e limites da noção de economia política do nome de "África” e da nebulosa conceitual que a atravessa e a orbita, que inclui aqui noções como “escritura da África”, nomenclausura, destinerrância, pertensimento, entre outras. Entre as condições desse diálogo fundamental está o 
três funções essenciais na modernidade - as funções de atribuição, interiorização e subversão”, Mbembe identifica três momentos associados à história da escritura da "África” no sistema colonial-moderno. ${ }^{41}$ Ao primeiro corresponde a inscrição da "África” como "um mundo à parte”, ${ }^{42}$ operando uma excrição do nome de “África” e da subjetivação racial do 'negro’ em relação à ideia de humanidade. "Posto à parte, posto à distância, parte à parte - foi assim que o negro veio a significar, em sua essência e antes que qualquer coisa seja dita, a exigência de segregação”, 43 enquanto, como “[f]igura viva da dessemelhança, o termo “África” remete consequentemente a um mundo à parte, [...] com o qual muitos dos nossos contemporâneos sentem dificuldade de se identificar”. ${ }^{44}$

Depois do momento da atribuição de diferença à “África” e ao "negro”, em um segundo momento “aconteceu que aqueles que haviam sido encobertos por essa alcunha - e haviam sido, consequentemente, postos à parte ou à distância - acabaram por habitá-la”, ${ }^{45}$ Por meio dessa "recuperação e interiorização”, afirma-se "uma política da diferença”, baseada na impossibilidade da partilha de um mundo comum. ${ }^{46}$ Finalmente, com base na reiteração da diferença e da separação da "África” e do "negro" em relação à humanidade e ao mundo comum, passa-se a um terceiro momento, marcado por um "gesto consciente de subversão, ora poético e ora carnavalesco”, ${ }^{47}$ que torna possível reconhecer o que está em jogo

reconhecimento da relação entre a "ordem do conhecimento" a que se refere Mudimbe e uma compreensão logocêntrica do discurso. Reconhecer essa relação é crucial não apenas para compreender a radicalidade da noção de "gnose", proposta por Mudimbe, mas também para articular a arqueologia do saber de Michel Foucault (A arqueologia do saber, Rio de Janeiro: Forense Universitária, 2008) a uma arqueologia do sensível, na qual se trata de pensar as imagens tanto em relação a discursos, saberes e conhecimentos, quanto em relação à vida sensível que as define (Emanuele Coccia, $A$ vida sensível, Desterro [Florianópolis]: Cultura e Barbárie, 2010).

41 Mbembe, Crítica da razão negra, p. 92.

42 Mbembe, Crítica da razão negra, p. 97.

43 Mbembe, Crítica da razão negra, p. 93.

44 Mbembe, Crítica da razão negra, p. 97.

45 Mbembe, Crítica da razão negra, p. 93.

46 Mbembe, Crítica da razão negra, p. 98.

47 Mbembe, Crítica da razão negra, p. 93. 
na reinscrição de Tarzan como um negro em Moi, un noir. O momento da reversão ou inversão "inaugura a plena e incondicional recuperação do estatuto de humanidade outrora rasurado pelo ferro e o açoite”. ${ }^{48}$ Como o Tarzan negro de Moi, un noir sugere, o que define essa tentativa de recuperação do estatuto de humanidade é, frequentemente, um jogo perturbador de mímica, que permanece marcado por uma ambiguidade irredutível, que Mbembe descreve como uma ambiguidade "semelhante a uma máscara”:

Sabemos que uma das funções da máscara sempre é esconder um rosto, duplicando-o - o poder do duplo, no cruzamento do ser e da aparência. A outra função é permitir a quem está mascarado ver os outros sem ser visto; ver o mundo como uma sombra escondida por baixo da superfície das coisas. Porém, se na máscara se cruzam o ser e a aparência, acontece que, na impossibilidade de ver o rosto que a máscara esconde - por essa minúscula fenda -, a máscara sempre acaba por se denunciar a si mesma como máscara. Assim, no drama da vida contemporânea, o nome “África” desempenha justamente a função de uma máscara. Pois, sempre que esse nome é invocado, cada corpo singular é automaticamente recoberto por muitos tecidos opacos. Está na própria essência desse nome convidar a uma operação de apagamento originário e de velamento que compromente a própria possibilidade da linguagem. Mais grave ainda: não será a África o próprio túmulo da imagem, um enorme sarcófago onde a luz é incapaz de se revirar e os membros inaptos para permitir tal deslocamento ${ }^{49}$

Qualquer inscrição do nome de “África” - num filme de Tarzan ou num ritual religioso de “origem africana”, numa notícia televisiva ou num desfile de moda com cenários e elementos "africanos”, numa reivindicação identitária afrodiaspórica ou em sonhos afrocêntricos e panafricanistas - deve ser concebida como atravessada pela sua excrição

48 Mbembe, Crítica da razão negra, p. 93.

49 Mbembe, Crítica da razão negra, pp. 99-100. 
em relação a outras possibilidades, isto é, sua retirada de redes discursivas e de tramas simbólicas que a encerram em determinados contextos e sua recolocação em outros contextos, conforme a "operação de apagamento originário e de velamento” a que se refere Mbembe. Como cada contexto permanece sempre aberto, inconcluso, insaturável, e como não é possível alcançar um lugar fora de todo contexto, um fora-de-texto que encerre a deriva do nome de “África”, cada inscrição da “África” se produz sempre como uma excrição diferida, adiada. A escritura da "África” consiste no trabalho da différance entre inscrição e excrição do nome de "África”, que emerge como "uma espécie de arbitrário primordial - esse arbitrário de designações às quais nada em particular parece precisar corresponder, a não ser o preconceito inaugural em sua regressão infinita”. ${ }^{50}$

Jacques Derrida denomina différance "o movimento pelo qual a língua, ou qualquer código, qualquer esquema de reenvios em geral se constitui ‘historicamente' como tecido de diferenças”. ${ }^{51}$ A différance entre inscrição e excrição do nome de “África” - isto é, a escritura da “África” - trabalha como uma dialética indecidível: reenviando interminavelmente de um termo a outro, de um lugar a outro, de um tempo a outro, de uma cultura a outra, a escritura da “África” como processo sócio-histórico não cessa de se fazer em movimento, sem que em algum momento se torne possível uma síntese última, transcendental, primeira. "Em outras palavras”, continua Mbembe, “dizer “África” consiste, pois, invariavelmente, em construir figuras e lendas - não importa quais - por cima de um vazio". ${ }^{52}$ Assim, se “o nome “África” desempenha justamente a função de uma máscara”, ${ }^{53}$ o que essa máscara recobre é um vazio: não existe rosto por trás da máscara.

50 Mbembe, Crítica da razão negra, p. 100.

51 Derrida, Margens da filosofia, p. 43.

52 Mbembe, Crítica da razão negra, p. 101.

53 Mbembe, Crítica da razão negra, p. 99. 
É o que faz de África um conjunto proliferante por excelência, uma potência tão devoradora que quase nunca secreta seu próprio onirismo, mas tende quase sempre a remeter ao sonho de um outro. Uma vez que o nome pode se tornar objeto de um novo nome, que designe outra coisa que não o objeto primeiro, pode-se, portanto, dizer da África que é o símbolo daquilo que está tanto fora da vida quanto para além da vida. É aquilo que se presta à repetição e à redução - a morte reiterada na vida, e a vida que habita a máscara da morte, nas fronteiras desta impossível possibilidade que é a linguagem. ${ }^{54}$

Assim como, em termos mais gerais, a ideologia recorta a infinita semiose da linguagem, cada regime de inscrição e excrição do nome de “África” recorta a escritura da "África” como processo aberto e descentrado, inconcluso, "nas fronteiras desta impossível possibilidade que é a linguagem”. ${ }^{55}$ Nesse sentido, o ocidentalismo - que Fernando Coronil define como um conjunto de práticas e de estratégias de representação que produzem tanto a figura múltipla do Outro em inúmeras formas de alteridade, quanto a figura implícita e persistente do Mesmo - ${ }^{56}$ constitui um regime de inscrição e excrição do nome de “África”. O ocidentalismo - que Walter Mignolo define como a versão ocidental da civilização ocidental, a autodescrição do Ocidente que permeia e atravessa o imaginário do sistema mundial colonial-moderno $-^{57}$ recorta e delimita, na escritura da “África”, uma nomenclausura: um programa denominativo, um campo de referencialidade, uma atmosfera associativa, um conjunto de regras de ilusão e de alusão distribuídas como um código, isto é, em suma, um sistema de reenvios.

Como um sistema de reenvios, a nomenclausura ocidentalista da “África” é construída historicamente e se reproduz, atualmente,

54 Mbembe, Crítica da razão negra, p. 101.

55 Mbembe, Crítica da razão negra, p. 101.

56 Coronil, "Beyond Occidentalism”.

57 Mignolo, Histórias locais - projetos globais. 
como um enquadramento cultural que pesa sobre qualquer discurso sobre a África, em torno do nome de “África” ou a partir de alguma “África”, continental ou diaspórica. Qualquer interrogação da escritura da “África” e da economia política do nome de “África” não deve se deixar enquadrar por nenhuma forma de nomenclausura e por nenhum regime de inscrição e excrição do nome de “África”. No entanto, seu fundamento sempre permanece contingente: só é possível interrogar a escritura da "África” a partir de alguma nomenclausura e de algum regime da economia política do nome de “África”, a partir de algum contexto. Trata-se de fazer entrever a totalidade, que nunca se apresenta como tal, a partir dos fragmentos que a compõem e das perspectivas singulares que abrem sobre sua construção. Um contexto nunca se fecha completamente, restando fendas a partir das quais se pode entrever outros sentidos.

A escritura da “África” como processo sócio-histórico resta sempre incompleta, o que equivale à impossibilidade de alcançar uma forma de inscrição-excrição do nome de “África” que apresente a África mesma, isto é, que a torne imediatamente presente a si, revelando seu rosto, como se existisse algum rosto por trás da máscara. A África mesma, tomada além de si, numa dialética indecidível: a escritura da “África” como différance implica já um espaçamento e uma temporalização que cindem a identidade do mesmo. Derrida escreve: “O mesmo é, precisamente, a diferança [différance] [...] como passagem desviada e equívoca de um diferente para outro, de um termo da oposição para o outro". ${ }^{58}$ Todo discurso sobre a África passa pela dialética indecidível de inscrição e excrição que constitui a escritura da “África”: recorta-a e delimita, dentro dela, um campo de pertinência além do qual as representações movimentadas pelo discurso deixam de ser plausíveis, isto é, uma nomenclausura. Nesse sentido, a escritura da "África” abriga diferentes campos discursivos que se relacionam entre si segundo o que chamo

58 Derrida, Margens da filosofia, p. 50. 
de economia política do nome de "África": o processo que articula e organiza os diferentes regimes existentes de inscrição e excrição do nome de "África”, as diferentes formas de nomenclausura da "África”.

Recebido em 27 ago. 2020

Aprovado em 10 abr. 2021

doi: 10.9771/aa.v0i63.38589 
Desde 1912, inúmeros textos - romances, programas de rádio, histórias em quadrinhos, seriados de televisão, filmes - produziram e articularam representações da África em narrativas envolvendo Tarzan, criado pelo estadunidense Edgar Rice Burroughs (1875-1950). Tomando o nome de "África” como referência, os textos que orbitam e habitam o nome de "Tarzan" pertencem a uma genealogia ocidental e a uma história transcultural. Após abordar a economia da marca registrada "Tarzan (®) em sua circulação global, uma descrição breve e esquemática da filmografia de Tarzan me permite interrogar o que chamo de nomenclausura ocidentalista da “África”. Finalmente, por meio de uma leitura atenta de Moi, un noir (1959), de Jean Rouch, como um prisma através do qual a circulação global de Tarzan pode ser interpretada e reinventada, sugiro possibilidades de transbordamento imaginativo, abrindo o espaçamento transcultural da escritura da "África" como economia política do nome de "África”.

Cinema | África | Tarzan | Racismo.

Tarzan, a Black Man: ToWard a Critique

of the Politcal Economy of the Name of "Africa"

Since 1912, countless texts - novels, radio shows, comic strips, television serials, films - have produced and articulated representations of Africa in narratives featuring Tarzan, a character created by the US author Edgar Rice Burroughs (1875-1950). Taking the name of "Africa" as a reference, the texts which surround and inhabit the name of "Tarzan" belong both to a Western genealogy and to a cross-cultural history. After examining the economy of the global circulation of the "Tarzan" trademark, I give a brief and schematic description of Tarzan's filmography, which allows me to interrogate what I call the occidentalist name-in-closure of "Africa". At last, by means of a close reading of Jean Rouch's Moi, un noir (1959) as a prism through which Tarzan's global circulation can be interpreted and reinvented, I suggest possibilities of imaginative overflow, opening up the cross-cultural spacing of the writing of "Africa" as political economy of the name of "Africa".

Cinema | Africa | Tarzan | Racism 